\title{
Problems and Reform Ideas of China's Legal Education System
}

\author{
Lian $\mathrm{Hu}^{1 *}$ \\ ${ }^{1}$ School of Law, Humanities and Social Sciences, Wuhan University of Technology, Wuhan, Hubei, China \\ *Emial:1056178283@qq.com
}

\begin{abstract}
Nowadays, legal education plays a very important role in a country and society. Excellent legal talents cultivated by excellent legal education will make a significant contribution to a country and society. However, at this stage, China' s legal education system is still not sound enough, and its problems are mainly manifested in: law degree and school running level, curriculum system and curriculum setting level, teaching method and teaching method level, teaching scale and teaching quality level.
\end{abstract}

Keywords: Legal education, system, problems

\section{PROBLEMS IN CHINA'S LEGAL EDUCATION SYSTEM}

\section{1. law degree and school-running level}

Due to historical and practical development factors, the degree of legal education in our country has been repeatedly added, with overlapping levels, a wide variety of varieties, and the division of specialties. Under such circumstances, there is a lack of linkage between degree levels, and the educational levels and channels are too large and complex, which can easily lead to confusion in education management and breakdown of the teaching staff, which will seriously affect the quality of teaching and damage the overall legal education. Image. [1]

At present, China's legal education has not yet achieved classification and gradual progress, and there is no clear first degree system in law, which has caused the degree of education system and education mechanism to be unsuccessful. Secondly, the law degree system lacks flexibility and flexibility. It places too much emphasis on higher-level legal education, and relatively ignores junior college and undergraduate courses. There is a lack of target differences between different law majors, and the talent positioning and recruitment ratios of professional degrees and research degrees are unreasonable. Each type of degree program has training objectives, training programs, curriculum settings, teaching methods and graduation (thesis) design The similarities and the minor differences result in serious homogeneity of the trained students, which cannot meet the differentiated needs of legal talents in social development.

\section{2. curriculum system and curriculum setting level}

The current legal education system in China has problems that cannot be ignored, that is, the lack of rationality in the curriculum setting, the unobvious specialty uniqueness, the lack of a unified curriculum system construction, curriculum setting, and teaching programs for various law majors across the country. [2]

Specifically, the law courses set up by some universities at the undergraduate level include two parts: compulsory and optional. In addition to studying the core professional courses, students can also choose optional courses that they are interested in, which improves students' learning autonomy to a certain extent. However, this kind of curriculum is still compulsory and supplemented by optional courses. Most of the courses are based on theory, lacking practicality and communication, which greatly reduces the teaching effect. At present, China's training objectives for different types of postgraduates are not clear, and the classification criteria are not clear, either. Traditional legal education focuses on cultivating academic talents, lacks a systematic design of legal professional education training, focuses too much on theory, lacks an effective practical legal education curriculum system, and lacks a team of teachers with practical experience and professional education. The current evaluation system for college 
teachers in China mainly focuses on scientific research results and theoretical articles. As for the accumulation of practical experience that meets the characteristics of the law profession, it is not used as a basis for evaluation. What's more, law teachers in our country undertake the main task of training law students. There are few courses like court mediation, court defense, court trial practice or lawyer internship. Although there is an internship period of nearly half a year, the pressure of students based on various graduation matters such as postgraduate entrance examinations and employment is not taken seriously; internship institutions do not trust the actual abilities of intern students, and are less willing to bear risks and investment costs for them, even if they accept them. The so-called vocational skills training of interns is often "miscellaneous" or mere formality.

\subsection{The level of teaching methods and teaching tactics}

At present, the traditional law education of higher education institutions in China generally adopts classroom dictation, and occasionally there are classroom discussions and case analysis. However, the teaching method is still single and lacks innovation. It cannot stimulate students, interest or mobilize students. Initiative, the teaching effect is not optimistic. The teaching ideology and teaching philosophy have not improved significantly. The school still implements examination-oriented education, [3] centered on examinations, and the teaching objectives and teaching content are too rigid. They only emphasize the transfer of knowledge and lack the exchange of ideas between teachers and students, which is also not conducive to law students' speculation. [4] The improvement of ability and the excavation of professional potential also neglect the cultivation of students' practical ability. This kind of education mode restricts the development of students, will cause the loss of talents in all fields, and it will be difficult to adapt to the development of the market economy and the construction of the legal system. This kind of education model is divorced from judicial practice, divorced from the legal profession itself, ignores the actual needs of society, only focuses on teaching, and lacks awareness of market competition and market demand.

\subsection{The level of teaching scale and teaching quality}

In contemporary society, the contradiction between the legal education system of our country and the society's demand for high-quality legal talents is also reflected in the contradiction between the scale of legal education and the quality of education. The scale and quality of legal education seriously affect the quality of training talents and the pressure of employment. If we blindly expand the scale of legal education, it will reduce the quality of talent training and increase employment pressure. As my country's higher education is gradually turning to popularization, the scale of legal education will also expand, but the quality of legal education cannot be guaranteed. The expansion of the scale of legal education has made the decline in the quality of legal education a very serious problem, which may even prevent the further development of legal education, and the decline in the quality of legal education will also lead to a decline in the overall quality of legal professionals.

\section{THINKING OF CHINA' S LEGAL EDUCATION REFORM}

\subsection{Change traditional teaching methods and combine theory with practice}

First, to reform the curriculum. [5] Law schools should offer relevant courses, including training on legal professional practice and courses on professional ethics, to change the current unhealthy status quo of law graduates, improve professional quality, improve practical ability, and improve the understanding of knowledge structure.

Second, to improve our country's teaching methods. The use of moot courts and the implementation of online teaching methods are better understood by students and have strong practicality, so that students' ability to solve and analyze problems can be improved. We can also learn from the excellent practical experience of foreign countries, and introduce foreign excellent content in practical legal teaching, such as legal debate class, mock court class, legal document writing class and so on. Teachers can also tell students the examples they have accumulated in social practice to help students have a deeper understanding of the specific procedures and actual environment of their future work, so that students can enhance their abilities in a targeted manner in the next study. [6]

Third, to reform the examination method. The forms of examinations should be diversified. In addition to written examinations, it is necessary to assess students' practical and expression skills, and allow students to discuss in groups, and the results will be included in the test scores.

\subsection{Adjust the setting of law degree}

The level of law degree setting China should stipulate a unified legal status in the legal profession, and take undergraduates or graduate students as the starting point. If people have a wealth of knowledge and experience to understand legal issues after receiving undergraduate education, law is the cultivation of political, economic, social and anthropological knowledge. The graduate degree should be the first degree. If a person' $\mathrm{s}$ 
knowledge is relatively narrow, but has a thorough understanding of some fraud, lawsuits, torts, contracts, and criminal acts, then an undergraduate student should be the first degree. This not only preserves the number of legal talents, but also guarantees the quality of legal education. Therefore, legal education greatly promotes the legal profession. High-quality legal education will cultivate high-quality legal talents, making legal education and legal professions tighter. Connected.

\subsection{Reorient the goal of legal education}

Repositioning the goal of legal education Economic globalization is developing rapidly. China should reposition its legal education training goals, and the political culture of various countries is moving towards integration. Jurists should move closer to international exchanges and cooperation. In recent years, China has deepened the reform of the education system and quality education. It exists in legal education, but too many majors are still a problem. There are more teaching methods and examination methods that are lagging behind, and students' practical ability is not strong. Therefore, we must reposition the goal of legal education in our country. This is the solution and the root of the problem. To make law education and the legal profession closely adjacent, and to increase the employment rate of the law profession, it is necessary to cultivate talents in the field of law in order to solve the problems in the legal profession. In addition, the key component of legal education is the strength of teachers, so it is crucial to strengthen the construction of the teaching staff. In the process of the increasing development of the times, the society has gradually stricter demand for legal talents, and teachers should pay attention to the improvement and update of self-knowledge and skills, impart professional knowledge to students, and use legal knowledge flexibly in the process of problem-solving. Colleges and universities also need to clarify the assessment and recruitment system for outstanding teachers, to maximize the legal professional ability of the teaching team, to form a high-quality and high-level legal teaching team, and to expand the scale of legal teaching. [7]

\subsection{Strengthen teaching management}

The problems in the school's internal management affect the full play of practical law teaching in the reform of legal education. The neglect of management of teachers and students in colleges and universities has also caused some negative effects on the quality of law teaching. At present, in the practice of law teaching in colleges and universities in China, students are mainly required to complete the graduation thesis and graduation practice. Most of the students in the creation of graduation thesis in the process, is to refer to the existing literature, rarely carry out social investigation this research activities of the necessary steps, which is not conducive to the improvement of students' practical ability.[8] In terms of graduation practice, some universities do not pay attention to the management of graduation practice, so that some students can only issue the internship certificate, not to really study, losing the due role of graduation practice. At the same time, most of the students are only responsible for daily chores in the graduation practice, and seldom get to know the professional work, which cannot make the students get the substantial promotion. In this situation, colleges and universities should strengthen the teaching management, set up special institutions, formulate corresponding teaching rules, strengthen the planning and supervision of the practical law teaching, and give full play to the role of the practical law teaching.

\section{CONCLUSION}

The construction of China's legal system and legal education are constantly improving, and great achievements have been made. Legal education has received more attention. At the same time, China has also formed a unique legal education system. With the continuous expansion of the scale of legal education, many problems have appeared frequently, facing the new political, economic and cultural social environment at home and abroad, China needs to reform the legal education system so as to improve the quality of legal education, cultivate a large number of outstanding legal talents, and make contributions to the construction of socialism. Therefore, this article mainly puts forward the problems existing in our country's legal system, and suggests relevant policies to these problems, hoping to be helpful to the improvement of our country's legal education system.

\section{REFERENCES}

[1] Feng Y.J., A Brief Discussion on the Problems Existing in the Current Education System in China [J]. Collection of Political and Law, 2014, 02(01): 83-90.

[2] Zheng H.Y., Ge C.R., Analysis of the status quo of legal practice teaching in provincial universities and research on countermeasures Research [J]. Beihua University Journal (Social Science Edition), 2014(05):145-147.

[3] Zhang Y.P., Research on the Application of Case Teaching Method in Adult Legal Education [J]. Adult Education, 2016 (06): 86-89.

[4] Luo L.P., Wu X.J., On the existing problems in the current legal education system in China [J]. Science and Wealth, 2015(z1):554-555.

[5] Li R., Research on the Employment 
Status and Employment Competitiveness Cultivatio $\mathrm{n}$ Countermeasures of University Law Majors [J]. SME Management and Technology, 2014(12): 309.

[6] Dai C.S., The role and application of practical legal teaching in the reform of legal education $[\mathrm{J}]$. Legal Expo, 2021 (03): 183-184.

[7] Wen T., The duality of legal education and the reform of Chinese legal education $[\mathrm{J}]$. Electronic Engineering College Journal, 2019, 08(10): 4-5.

[8] Wei W., Discussion on the support for the cultivation of legal talents in colleges and universities based on the subject platform $[\mathrm{J}]$. Legal System Expo, 2021, 04(07): 179-180. 